\title{
Colostrum protein uptake in neonatal lambs examined by descriptive and quantitative liquid chromatography-tandem mass spectrometry
}

\author{
Lorenzo E. Hernández-Castellano, ${ }^{\star} \dagger$ Anastasio Argüello, ${ }^{*}$ André M. Almeida, $¥ \S$ Noemí Castro, ${ }^{* 1}$ \\ and Emøke Bendixen\# \\ *Department of Animal Science, Universidad de Las Palmas de Gran Canaria, 35413 Arucas, Gran Canaria, Spain \\ †Veterinary Physiology, Vetsuisse Faculty, University of Bern, Bremgartenstrasse 109a, CH-3001 Bern, Switzerland \\ łlnstituto de Investigação Científica Tropical (IICT) and Centro Interdisciplinar de Investigação em Sanidade Animal (CIISA), 1300-142 Lisboa, \\ Portugal \\ §Instituto de Biologia Experimental e Tecnológica (IBET) and Instituto de Tecnologia Química e Biológica da Universidade Nova de Lisboa \\ (ITQB/UNL), 2780-157 Oeiras, Portugal \\ \#Department of Molecular Biology and Genetics, Aarhus University, 8000 Aarhus, Denmark
}

\begin{abstract}
Colostrum intake is a key factor for newborn ruminant survival because the placenta does not allow the transfer of immune components. Therefore, newborn ruminants depend entirely on passive immunity transfer from the mother to the neonate, through the suckling of colostrum. Understanding the importance of specific colostrum proteins has gained significant attention in recent years. However, proteomics studies of sheep colostrum and their uptake in neonate lambs has not yet been presented. The aim of this study was to describe the proteomes of sheep colostrum and lamb blood plasma, using sodium dodecyl sulfate-PAGE for protein separation and in-gel digestion, followed by liquid chromatography-tandem mass spectrometry of resulting tryptic peptides for protein identification. An isobaric tag for relative and absolute quantitation (iTRAQ)-based proteomics approach was subsequently used to provide relative quantification of how neonatal plasma protein concentrations change as an effect of colostrum intake. The results of this study describe the presence of 70 proteins in the ovine colostrum proteome. Furthermore, colostrum intake resulted in an increase of 8 proteins with important immune functions in the blood plasma of lambs. Further proteomic studies will be necessary, particularly using the selected reaction monitoring approach, to describe in detail the role of specific colostrum proteins for immune transfer to the neonate.
\end{abstract}

Key words: colostrum, immunity, proteomics, isobaric tag for relative and absolute quantitation (iTRAQ)

Received March 17, 2014.

Accepted September 25, 2014.

${ }^{1}$ Corresponding author: noemi.castro@ulpgc.es

\section{INTRODUCTION}

It is well known that early colostrum intake is a key factor for neonatal survival in mammals. In ruminants, the complexity of the synepitheliochorial placenta does not allow sufficient transfer of immunoglobulins from the dam to the fetus (Argüello et al., 2004a; Castro et al., 2005, 2011). Consequently, lambs are classified as hypo-gammaglobulinemic at birth, and are entirely dependent on passive immunity transfer (PIT) from the mother to the neonate through early suckling of colostrum (Stelwagen et al., 2009; Danielsen et al., 2011). Colostrum contains essential nutrients such as fat, lactose, vitamins, and minerals (Ontsouka et al., 2003; Hernández-Castellano et al., 2014a; Lérias et al., 2014 ), but it is also rich in unique proteins that play active roles in regulating growth and development of the gut tissue. Colostrum also protects the neonate against pathogens and postpartum environmental challenges (Bendixen et al., 2011; Hernández-Castellano et al., 2015).

Although the transfer of immunoglobulins is a key factor in host defense to pathogens, a wider range of colostrum components have been suggested to contribute to the early protection of the neonate (Smith and Foster, 2007). These include many unique proteins with specific functional roles, including proteins secreted by neutrophils and macrophages, blood complement system proteins, acute-phase proteins, and specific proteins and peptides that have direct antimicrobial activity (Rainard and Riollet, 2006; Oviedo-Boyso et al., 2007; Leitner et al., 2008). In addition to mediating host defense, a wide range of bioactive colostrum proteins also play important roles as key regulators of gastrointestinal growth and development in early life (Bendixen et al., 2011).

Colostrum proteins are protected by trypsin inhibitors present in colostrum (Ramos et al., 2010; Hernán- 
dez-Castellano et al., 2014a), as well as by low proteolytic activity in the gastrointestinal tract of newborn animals (Guilloteau et al., 1983). Additionally, the uptake of entire proteins through the gut epithelium is facilitated by unique features of a regulated apoptotic process of the neonatal ruminant enterocytes, which allows unrestricted passage of large molecules, such as immunoglobulins, into the gut (Castro-Alonso et al., 2008; Stelwagen et al., 2009). It is crucial to feed newborn ruminants colostrum during the first $48 \mathrm{~h}$ after birth, because the mechanisms that facilitate PIT and colostrum uptake are only functional in the first days of life (Moore et al., 2005; Hernández-Castellano et al., 2014b). Neither the cellular mechanisms of colostrum protein transfer to blood nor their bioactive roles in the neonate ruminants are fully understood. Although bovine milk and colostrum proteomes have attracted much attention, including reports of more than 253, 138, and 403 proteins characterized in colostrum and milk whey (Le et al., 2011), milk fat globule membrane (Reinhardt and Lippolis, 2008), and colostrum samples (Reinhardt and Lippolis, 2008; Le et al., 2011; Nissen et al., 2012), respectively, very limited knowledge seems to be available on sheep colostrum proteins. Some ELISA-based studies have reported concentration levels of $\mathrm{IgG}$ in sheep colostrum to range from 48.1 to 60.9 $\mathrm{mg} / \mathrm{mL}$ (Moretti et al., 2010a,b; Higaki et al., 2013) and in newborn lamb plasma from 13.7 to $26.6 \mathrm{mg} / \mathrm{mL}$ (Quigley et al., 2002; Rodinova et al., 2008). However, proteomic studies of sheep colostrum proteins and their uptake in neonate lambs has not yet been performed.

The aim of this study was to describe the proteomes of sheep colostrum and lamb blood plasma, using an SDS-PAGE for protein separation and in-gel digestion, followed by liquid chromatography-tandem mass spectrometry (LC-MS/MS) of resulting tryptic peptides for protein identification. An isobaric tag for relative and absolute quantitation (iTRAQ)-based proteomics approach was subsequently used to provide relative quantification of changes in neonatal plasma protein concentrations as an effect of early colostrum intake.

\section{MATERIALS AND METHODS}

\section{Animal Experimentation Disclosure}

This experiment was approved by the ethics committee of the Universidad de Las Palmas de Gran Canaria (Spain) in compliance with animal experimentation regulations in the Canary Islands, Spain, and the European Union. A. M. Almeida holds a Federation of Laboratory Animal Science Associations (FELASA) grade $\mathrm{C}$ license, enabling him to design and conduct animal experiments in the European Union.

\section{Sample Collection}

The study was based on individual analysis of plasma samples from 8 single partum lambs (Canarian dairy breed), studied as 2 experimental groups (4 lambs each), as well as 2 samples from the pool of colostrum used for lamb feeding. As dams were estrous synchronized and subsequently mated, all lambs were born in the same period (May 2012) with a difference of a few days. The experiment took place at the experimental farm of the Veterinary Faculty of the Universidad de Las Palmas de Gran Canaria (28 $8^{\prime} 20.66^{\prime \prime}$ N, 15 $30^{\prime} 24.97^{\prime \prime}$ W, Gran Canaria, Spain). During the experimental period (from birth until $14 \mathrm{~h}$ after birth), the colostrum (C) group received colostrum feeding at $2 \mathrm{~h}$ after birth; the nocolostrum (NC) group was not fed at $2 \mathrm{~h}$ after birth. To ensure survival of the animals, both groups were subsequently fed with colostrum after the experimental period at 14 and $26 \mathrm{~h}$ after birth. Animals were fed a common pool of sheep colostrum with an IgG concentration of $64.74 \mathrm{mg} / \mathrm{mL}$. Blood samples were collected directly before feeding at 2 and $14 \mathrm{~h}$ after birth from the jugular vein in 2.5-mL tubes with $\mathrm{K}$-EDTA. Blood was centrifuged at 2,190 $\times g$ for 5 min at $4^{\circ} \mathrm{C}$ (Hettich-Zentrifugen, Universal $32 \mathrm{R}$, Tuttlingen, Germany) and the obtained plasma was frozen at $-80^{\circ} \mathrm{C}$ until further analysis. All lambs were housed in rearing rooms with at least $0.3 \mathrm{~m}^{2}$ of floor space per lamb. Each room had central heating with a room temperature of approximately $20^{\circ} \mathrm{C}$.

\section{Sample Preparation}

Plasma and colostrum samples were analyzed at Aarhus University (Aarhus, Denmark). A total of $200 \mu \mathrm{L}$ from each sample were homogenized with $1 \mathrm{~mL}$ of TrisEDTA-sucrose (TES) buffer $(10 \mathrm{~m} M$ Tris-HCl, $\mathrm{pH}$ 7.6, $1 \mathrm{~m} M$ EDTA, $0.25 M$ sucrose) using an UltraTurrax homogenizer (T10 basic, IKA-Werke, Staufen, Germany) at 12,000 rpm. Homogenates were centrifuged at $10,000 \times g$ for $30 \mathrm{~min}$ at $4^{\circ} \mathrm{C}$ to remove insoluble components. Protein concentration of the supernatant was determined with the Quick Start Bradford Protein Assay (Bio-Rad, Hercules, CA), using BSA as standard reference (Bradford, 1976) and following the manufacturer's instructions. Aliquots of $100 \mu \mathrm{g}$ of protein from each sample were recovered after precipitation with 6 volumes of ice-cold acetone $\left(-20^{\circ} \mathrm{C}\right)$ and centrifugation at $15,000 \times g$ for $10 \mathrm{~min}$ at $4^{\circ} \mathrm{C}$.

For the descriptive analyses of plasma and colostrum proteomes, $60 \mu \mathrm{g}$ of protein from the experimental groups (C and NC groups) at $14 \mathrm{~h}$ (2 biological replicates from each group) as well as the pooled colostrum used for the feeding experiment were prepared (2 technical replicates). Aliquots were resuspended in $20 \mu \mathrm{L}$ of TES buffer. The 
samples were boiled for $5 \mathrm{~min}$ in SDS sample buffer $(7.5$ $\mathrm{mL}$ ) containing $500 \mathrm{mM}$ DL-dithiothreitol (DTT), separated by SDS-PAGE using 10\% (wt/vol) acrylamide gels (Bury, 1981) and stained using Coomassie blue (RAPIDstain, G-Biosciences, Maryland Heights, MO). Each lane was cut into 9 equal-sized pieces, each of which was washed 3 times in Milli-Q water (Millipore, Billerica, MA) and incubated 2 times for $15 \mathrm{~min}$ in $130 \mu \mathrm{L}$ of $50 \%$ acetonitrile, dehydrated in $130 \mu \mathrm{L}$ of acetonitrile for 15 min, and equilibrated in $150 \mu \mathrm{L}$ of $0.1 M^{M} \mathrm{NH}_{4} \mathrm{HCO}_{3}$ for $5 \mathrm{~min}$ before $150 \mu \mathrm{L}$ of acetonitrile was added. After 15 min, supernatants were removed and gel pieces were dried by vacuum (SpeedVac, Thermo Fisher Scientific, Waltham, MA) for $20 \mathrm{~min}$. In-gel digestions were performed by incubating the gel pieces with sequencinggrade modified trypsin (Promega, Southampton, UK) in $50 \mathrm{mM} \mathrm{NH} \mathrm{NH}_{4} \mathrm{HCO}_{3}$ at $37^{\circ} \mathrm{C}$ for $16 \mathrm{~h}$, using $400 \mathrm{ng}$ of trypsin for heavily loaded gel pieces, and $200 \mathrm{ng}$ of trypsin for fainter gel pieces (Supplemental Figure S1; http://dx.doi.org/10.3168/jds.2014-8143). The resulting peptides were desalted using $\mathrm{C}_{18}$ StageTips (Thermo Scientific, Hvidovre, Denmark) and stored at $-20^{\circ} \mathrm{C}$ before LC-MS/MS analysis.

\section{LC-MS/MS Analysis}

Analyses of gel pieces by LC-MS/MS was performed on an EASY-nLC II system (Thermo Scientific) connected to a TripleTOF 5600 mass spectrometer (AB Sciex, Framingham, MA) equipped with a NanoSpray III source (AB Sciex) and operated under Analyst TF 1.6 control. Tryptic peptides were dissolved in $15 \mu \mathrm{L}$ of buffer A (0.1\% formic acid), injected, trapped, and desalted isocratically on a ReproSil-Pur C18-AQ column $(5 \mu \mathrm{m}, 2 \mathrm{~cm} \times 100 \mu \mathrm{m}$ i.d; Thermo Scientific). Then, peptides were eluted from the trap column and separated on a ReproSil-Pur C18-AQ 3- $\mu$ m capillary column $(16 \mathrm{~cm} \times 75 \mu \mathrm{m}$ i.d. $)$ connected in-line to the mass spectrometer at $250 \mathrm{~nL} / \mathrm{min}$ using a 50 -min gradient from $5 \%$ to $35 \%$ of buffer B $(0.1 \%$ formic acid and $90 \%$ acetonitrile), followed by a $10-$ min re-equilibration time in buffer A. The TripleTOF 5600 was run in positive ion mode using $2,500 \mathrm{~V}$ for ion spray, curtain gas at $30 \mathrm{psi}$, ion source gas at $5 \mathrm{psi}\left(\mathrm{lbf} / \mathrm{in}^{2}\right)$, and an interface heater temperature of $150^{\circ} \mathrm{C}$. The automated information dependent acquisition (IDA) method acquired up to 50 tandem (ms/ms) mass spectra per cycle using 2.3 -s cycle times and a mass exclusion window of $6 \mathrm{~s}$.

\section{iTRAQ-Based Quantitative LC-MS/MS}

Six sets of iTRAQ experiments were designed to study the differential protein abundances found in plasma collected from the $\mathrm{C}$ and $\mathrm{NC}$ groups. Sixteen plasma samples were compared, including 4 biological replicates and 2 time points ( 2 and $14 \mathrm{~h}$ after birth) from both treatment conditions (C and $\mathrm{NC}$ ). Consistently, the iTRAQ reagent 114 was used to label an internal control sample made by pooling $100 \mu \mathrm{g}$ of plasma protein aliquots, including all 16 individual plasma samples. The remaining iTRAQ reagents $(115,116$, and 117) were used to label the 16 individual plasma samples.

Cysteine residues were reduced with $2.5 \mathrm{~m} M$ tris (2-carboxyethyl) phosphine hydrochloride at $60^{\circ} \mathrm{C}$ for $1 \mathrm{~h}$ and then blocked with $10 \mathrm{mM}$ methylmethanethiosulfate solution at room temperature for $10 \mathrm{~min}$. Proteins were then digested with trypsin $(1: 10 \mathrm{wt} / \mathrm{wt})$ at $37^{\circ} \mathrm{C}$ overnight. The tryptic peptides were labeled with iTRAQ reagents (Applied Biosystems, Forster City, $\mathrm{CA}$ ) at room temperature for $1 \mathrm{~h}$, following the manufacturer's instructions. Finally, samples were combined to create 6 different 4 -plexed samples.

\section{Strong Cation Exchange Fractionation and LC-MS/MS Analysis}

A total of $50 \mu \mathrm{g}$ of protein from each of the iTRAQ 4-plexed samples were loaded on an Agilent 1100 Series capillary HPLC equipped with a Zorbax Bio-SCX Series II (Agilent Technologies, Palo Alto, CA), and peptides were eluted with a gradient of increasing $\mathrm{NaCl}$ solution. Fractions were then collected every min for $65 \mathrm{~min}$ and combined according to their peptide loads into 9 to 10 pooled samples, which were individually analyzed on LC-MS/MS, using the Easy-nLC II system (Thermo Scientific) connected to a QSTAR Elite mass spectrometer (AB Sciex) equipped with a NanoSpray source (AB Sciex) and operated under Analyst QS 2.0 control. The trypsin-digested samples were dissolved in buffer A (0.1\% formic acid), injected, trapped, and desalted isocratically on a ReproSil-Pur C18-AQ column (5 $\mu \mathrm{m}, 2 \mathrm{~cm} \times 100 \mu \mathrm{m}$ i.d.; Thermo Scientific), after which the peptides were eluted from the trap column and separated on an analytical ReproSil-Pur C18-AQ capillary column $(3 \mu \mathrm{m}, 10 \mathrm{~cm} \times 75 \mu \mathrm{m}$ i.d.; Thermo Scientific) connected in-line to the mass spectrometer at $250 \mathrm{~nL} / \mathrm{min}$ using a 63 -min gradient from $5 \%$ to $38 \%$ of buffer B (0.1\% formic acid and 90\% acetonitrile). The QSTAR Elite MS was run in positive ion mode using $2,600 \mathrm{~V}$ for ion spray, curtain gas at $20 \mathrm{psi}$, ion source gas at 1:16, and an interface heater temperature of $110^{\circ} \mathrm{C}$. The automated IDA method was set to acquire up to $3 \mathrm{MS} / \mathrm{MS}$ spectra per cycle using $2.0 \mathrm{~s}$ cycle times and an exclusion window of $80 \mathrm{~s}$.

\section{Protein Identification and Quantitation}

The collected MS files were converted to Mascot generic format (MGF) using the AB Sciex MS Data Con- 
verter $\beta 1.3$ (AB Sciex), and the "proteinpilot MGF" parameter. The peak lists were used to interrogate a combined bovine, ovine, and caprine database consisting of sequences from TrEMBL/Swiss-Prot (http:// www.uniprot.org/uniprot/) and NCBInr (http://www. ncbi.nlm.nih.gov/protein) (32,444 sequences), using Mascot 2.3.02 (Matrix Science, London, UK; Perkins et al., 1999). As previously described by Soares et al. (2012), the combination of phylogenetically close species is a strategy typically used when the experimental species do not have complete sequence databases. For in-gel digests, the search parameters were set to allow one missed trypsin cleavage site and propionamide as a fixed modification. The mass accuracy of the precursor and product ions were $15 \mathrm{ppm}$ and $0.2 \mathrm{Da}$ and the instrument settings were specified as ESI-QUADTOF. Only proteins with at least 2 unique peptides and a minimal protein score of 60 were considered for identification (Boersema et al., 2008; Gannon and Ohlendieck, 2012; Hernández-Castellano et al., 2014b). The whole identification list can be observed in Supplemental Table S1 (spreadsheet; http://dx.doi. org/10.3168/jds.2014-8143).

For the iTRAQ samples, the search parameters were set to allow one missed trypsin cleavage site and methylthiomethanesulfate modification of cysteine was set as fixed modification, and oxidation of methionine was defined as a variable modification. The iTRAQ 4-plex was selected as the quantitation method. The mass accuracy of the precursor and product ions were set to 0.2 Da using instrument setting as ESI-QUAD-TOF. The significance threshold ( $P$-value) was set to 0.01 with an ion score cutoff at 31 for all samples. Only proteins with at least 2 unique peptides and a minimal protein score of 60 were considered for identification. Mascot results were parsed using MS Data Miner v.1.1 (Dyrlund et al., 2012). The report generated by the software includes data on mass $(\mathrm{kDa})$, ratio, peptides, and relative protein abundance. Supplemental Table S2 (spreadsheet; http://dx.doi.org/10.3168/jds.2014-8143) provides information about the final report generated by MS Data Miner v.1.1, comparing all identified and quantified proteins from the 6 sets of iTRAQ data.

\section{Statistical Analysis}

Statistical analyses from iTRAQ approach were tested for significance $(P<0.05)$ by ANOVA using PROC MIXED of SAS (version 9.0, SAS Institute Inc., Cary, NC). The model included time, treatment, and their interactions as fixed effects. A Tukey-Kramer adjustment was used to compensate for multiple comparisons.

\section{RESULTS AND DISCUSSION}

To investigate which proteins can be detected in colostrum and plasma using shotgun proteomics, we used an approach based on SDS-PAGE separation and LC-MS/MS-based protein identification. Only proteins observed in both biological replicates from each sample type (C and $\mathrm{NC}$ groups at $14 \mathrm{~h}$ after birth, as well as the colostrum pool used) were considered significant and unique observations. Analyses of the pooled colostrum used in our feeding experiment allowed identification of 70 proteins, whereas 64 and 97 proteins were observed in plasma from $\mathrm{C}$ and $\mathrm{NC}$ groups, respectively. The proteins observed in plasma from $\mathrm{C}$ group animals represent both original plasma proteins as well as the subset of proteins transferred from colostrum to plasma. Therefore, the aim of this initial and descriptive study was to collect detailed information about the protein subsets detectable in these 3 different and complex proteome samples and to provide information about the overlap, uniqueness, and origin of proteins from colostrum and plasma. The Venn diagram in Figure 1 presents an overview of the distribution of proteins across colostrum and plasma. It is important to note that 29 proteins were detected in all 3 studied groups (C and $\mathrm{NC}$ groups and the colostrum pool used). Moreover, comparing these proteome profiles demonstrated that a wide range of immunoglobulins originating from colostrum are transferred to plasma, whereas a large majority of colostrum-specific proteins were not detectable in plasma $12 \mathrm{~h}$ after suckling, indicating that transport of proteins from colostrum, over the gut epithelial layer, and into plasma is a controlled and selective process, although mechanisms responsible for selective transfer are not yet fully understood (Johnson et al., 2007).

Another interesting observation provided by our direct comparison of body fluid proteomes was that a much larger range of well-known plasma proteins and intracellular proteins (i.e., fructose-biphosphate aldolase and carbonic anhydrase) was detectable in plasma from animals that lacked access to colostrum compared with the plasma of colostrum-fed lambs. This is likely because peptide selection in shotgun-based LC-MS/MS analyses is greatly biased by the relative abundance of specific proteins and peptides in complex biological samples. Thus, in plasma collected after colostrum suckling, the high concentration of immunoglobulins present in plasma clearly outnumbered and overshadowed detection of the lower abundance plasma protein in the background (Millioni et al., 2011; Petersen et al., 2013).

To achieve a more direct comparison and to obtain relative quantification of the effect of colostrum feed- 
ing, an iTRAQ-based tagging approach was used to compare the plasma proteomes of 8 individually sampled animals. This investigation also aimed to study how access to colostrum affects the expression levels of plasma proteins related to growth and development of neonatal lambs.

In total, 148 proteins were detected in the iTRAQtagged analyses. Compared with similar shotgun analyses of bovine plasma (Faulkner et al., 2012) and colostrum (Reinhardt and Lippolis, 2008; Nissen et al., 2012), the number of proteins we could identify and quantify in colostrum and plasma samples of sheep was much lower. This was partly due to the dynamic range, as discussed above (Klobasa et al., 1987; Hortin and Sviridov, 2010) but was mainly a direct effect of the current lack of a well-covered reference ovine genome database. Indeed, detailed annotation of sheep proteins is very limited compared with the bovine and caprine databases.

The recent technological progress in targeted and absolute quantitation methods (Picotti et al., 2009) improves accuracy of analyses for future experiments. In particular, the development of candidate target proteins would largely benefit further studies of the absolute absorption of specific colostrum proteins in plasma. However, these methods require that specific proteotypic signature peptides are described and validated for each protein to be analyzed across tissues (Picotti et al., 2009).

\section{Protein Identification}

Table 1 provides a list of information about nonredundant proteins identified in colostrum and plasma samples from $\mathrm{C}$ and $\mathrm{NC}$ groups at $14 \mathrm{~h}$ after birth. The first group of proteins listed in Table 1 represents those identified in all samples (from colostrum as well as plasma). The second group represents the proteins that were uniquely found in plasma from colostrum-fed animals. This group is of particular interest because these proteins represent specific transfer from colostrum and, in our data, these are clearly dominated by immunoglobulins. The third set of proteins shown in Table 1 was identified exclusively in colostrum. Most of these are well known in bovine studies to be highly abundant in colostrum, including immunoglobulins and caseins, but also proteins from similar studies on bovine colostrum that are known to be of lower abundance. These include serum amyloid A-3, which was found to be present at $267 \mu \mathrm{g} / \mathrm{mL}$ (McDonald et al., 2001) and plasmin, reported to be present on $0.49 \mu \mathrm{g} / \mathrm{mL}$ (Dupont et al., 1998). Finally, the fourth group shows proteins that could only be detectable in animals that lacked access to colostrum (NC group). This list of pro-

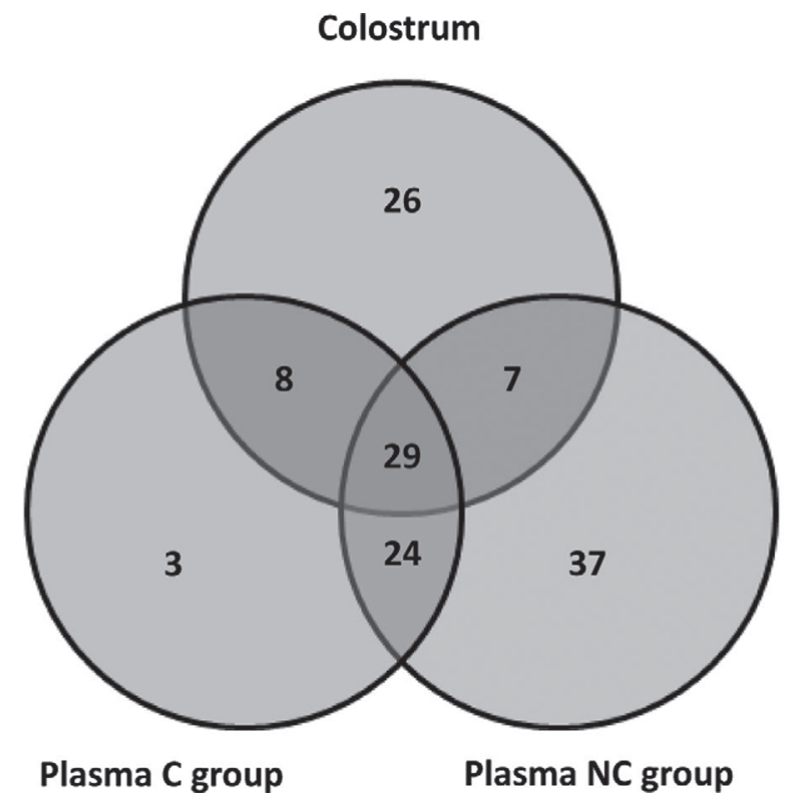

Figure 1. Venn diagram of colostrum pool and plasma from colostrum (C group) and noncolostrum ( $\mathrm{NC}$ group) lambs.

teins represents both the plasma proteome background, as well as the proteins secreted in plasma as a response to the physiological stress of lacking normal colostrum intake.

Proteins Identified in All Samples. Twenty-nine proteins were observed in plasma from all animals, regardless of colostrum feeding time, and in the pooled colostrum. For these proteins, it should be noted that some immunoglobulin components ( $\lambda$ and $\mu$ chains) could also be detected in the plasma of animals that had not yet received colostrum. Although several authors have noted that the ruminant placenta lacks the ability to transfer immunoglobulins from the dam to the fetus (Constant et al., 1994; Argüello et al., 2004b), other researchers (Argüello et al., 2004a; Gabriël et al., 2005; Rodríguez et al., 2009; Castro et al., 2011) are in agreement with our present findings that small but detectable amounts of immunoglobulins are indeed transferred through the placenta. Likewise, 4 apolipoprotein isoforms, fibrinogen, plasminogen, serotransferrin, ceruloplasmin, and trypsin inhibitor were present in all samples. These proteins are mainly known as components of blood, their presence also in cow colostrum has been confirmed and also includes apolipoproteins A-I, A-IV, and E (Yamada et al., 2002; Reinhardt and Lippolis, 2008), plasminogen (Dupont et al., 1998; Yamada et al., 2002), trypsin inhibitor (Honkanen-Buzalski and Sandholm, 1981; Yamada et al., 2002), ceruloplasmin (Albera and Kankofer, 2009), fibrinogen, and serotransferrin (Yamada et al., 2002). In some cases, these proteins have been reported to 
Table 1. Colostrum proteins identified in sheep colostrum and in lamb plasma from colostrum group (C group) and noncolostrum group (NC group)

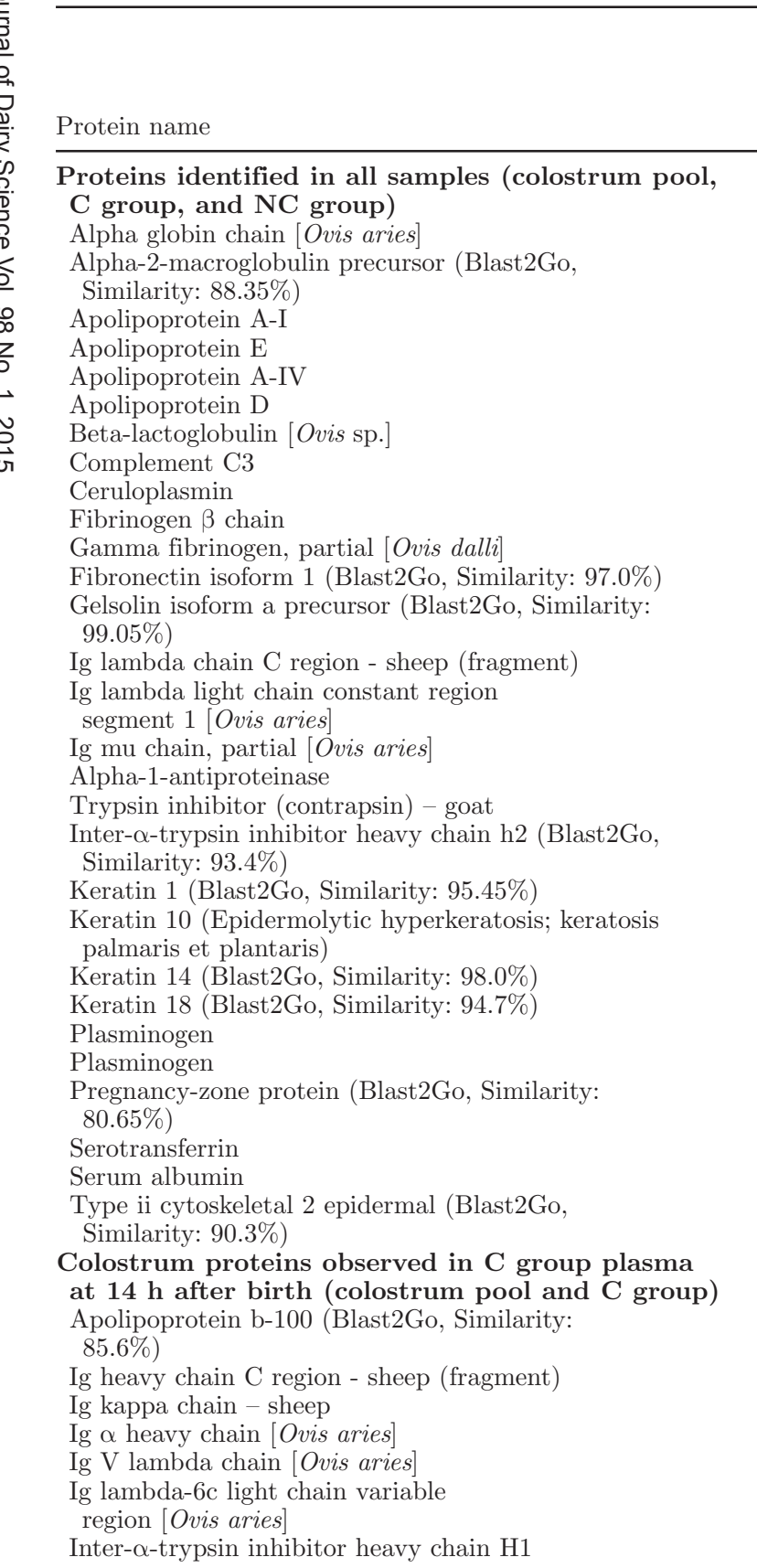

\begin{tabular}{|c|c|c|c|c|c|c|c|c|c|}
\hline \multirow[b]{2}{*}{$\begin{array}{l}\text { Accession } \\
\text { number }\end{array}$} & \multicolumn{3}{|c|}{ Mascot score } & \multicolumn{3}{|c|}{ Significant peptide matches ${ }^{1}$} & \multicolumn{3}{|c|}{ Unique peptide matches } \\
\hline & Colostrum & $\stackrel{\mathrm{C}}{\text { group }}$ & $\begin{array}{l}\mathrm{NC} \\
\text { group }\end{array}$ & Colostrum & $\underset{\text { group }}{\mathrm{C}}$ & $\begin{array}{l}\mathrm{NC} \\
\text { group }\end{array}$ & Colostrum & $\underset{\text { group }}{\mathrm{C}}$ & $\begin{array}{l}\mathrm{NC} \\
\text { group }\end{array}$ \\
\hline
\end{tabular}

\begin{tabular}{|c|c|c|c|c|c|c|c|c|c|}
\hline gi|1787 & 211 & 592 & 1,748 & 9 & 17 & 56 & 4 & 3 & 7 \\
\hline E1BJW0 & 3,808 & 3,811 & 5,212 & 158 & 138 & 210 & 7 & 16 & 18 \\
\hline P15497 & 2,151 & 2,402 & 4,308 & 86 & 79 & 171 & 9 & 16 & 22 \\
\hline gi 41016830 & 464 & 468 & 1,339 & 23 & 13 & 47 & 8 & 5 & 13 \\
\hline F1N3Q7 & 515 & 267 & 1,159 & 26 & 11 & 45 & 6 & 6 & 14 \\
\hline F1MS32 & 882 & 109 & 433 & 20 & 4 & 16 & 4 & 2 & 4 \\
\hline gi|165839 & 9,202 & 71 & 738 & 328 & 3 & 42 & 11 & 2 & 6 \\
\hline Q2UVX4 & 1,482 & 695 & 3,628 & 62 & 31 & 168 & 20 & 14 & 33 \\
\hline gi|75075054 & 773 & 448 & 1,091 & 28 & 13 & 7 & 5 & 6 & 3 \\
\hline F1MAV0 & 993 & 399 & 4,902 & 22 & 12 & 147 & 6 & 4 & 17 \\
\hline gi|1916272 & 66 & 247 & 1,140 & 5 & 13 & 40 & 2 & 2 & 2 \\
\hline G5E5A9 & 353 & 2,110 & 2,186 & 17 & 65 & 80 & 8 & 19 & 21 \\
\hline F1MJH1 & 123 & 522 & 1,753 & 7 & 20 & 78 & 4 & 6 & 16 \\
\hline gi|109030 & 5,307 & 3,704 & 146 & 137 & 83 & 6 & 5 & 6 & 2 \\
\hline gi| 52366986 & 4,999 & 3,533 & 572 & 133 & 96 & 20 & 6 & 6 & 2 \\
\hline gi| 165945 & 1,384 & 1,292 & 633 & 55 & 42 & 22 & 7 & 8 & 5 \\
\hline gi| 112890 & 447 & 1,597 & 5,175 & 24 & 84 & 248 & 8 & 12 & 17 \\
\hline gi|1363062 & 290 & 85 & 503 & 13 & 4 & 23 & 2 & 2 & 2 \\
\hline F1MNW4 & 375 & 691 & 1,126 & 16 & 25 & 45 & 5 & 6 & 10 \\
\hline G3N0V2 & 3,635 & 1,549 & 2,817 & 132 & 48 & 101 & 7 & 5 & 5 \\
\hline A6QNZ7 & 2,524 & 582 & 1,610 & 136 & 36 & 89 & 11 & 6 & 9 \\
\hline F1MC11 & 4,483 & 1,154 & 2,892 & 150 & 42 & 102 & 12 & 6 & 8 \\
\hline F6S1Q0 & 390 & 146 & 273 & 33 & 9 & 23 & 3 & 2 & 2 \\
\hline gi|3914364 & 82 & 377 & 905 & 3 & 17 & 48 & 2 & 4 & 8 \\
\hline E1B726 & 442 & 264 & 677 & 25 & 10 & 30 & 2 & 3 & 5 \\
\hline F1MI18 & 393 & 367 & 362 & 11 & 15 & 15 & 2 & 4 & 4 \\
\hline G3X6N3 & 201 & 5,826 & 9,563 & 18 & 195 & 369 & 4 & 19 & 21 \\
\hline gi|113582 & 3,228 & 21,245 & 36,037 & 136 & 658 & 1,163 & 23 & 45 & 51 \\
\hline E1B991 & 2,230 & 964 & 1,802 & 78 & 28 & 61 & 5 & 3 & 3 \\
\hline
\end{tabular}

E1BNR0

gi| 109029

gi| 423311

gi 2582411

gi| 2766644

gi| 2746699

Q0VCM5
$964 \quad 1,802$

$\begin{array}{rrr}394 & 750 & \text { ND }^{2} \\ 7,557 & 1,200 & \text { ND } \\ 258 & 345 & \text { ND } \\ 864 & 113 & \text { ND } \\ 108 & 138 & \text { ND } \\ 219 & 408 & \text { ND } \\ & & \\ 200 & 201 & \text { ND }\end{array}$

西


Table 1 (Continued). Colostrum proteins identified in sheep colostrum and in lamb plasma from colostrum group (C group) and noncolostrum group (NC group)

\begin{tabular}{|c|c|c|c|c|c|c|c|c|c|c|}
\hline \multirow[b]{2}{*}{ Protein name } & \multirow[b]{2}{*}{$\begin{array}{l}\text { Accession } \\
\text { number }\end{array}$} & \multicolumn{3}{|c|}{ Mascot score } & \multicolumn{3}{|c|}{ Significant peptide matches ${ }^{1}$} & \multicolumn{3}{|c|}{ Unique peptide matches } \\
\hline & & Colostrum & $\begin{array}{l}\mathrm{C} \\
\text { group }\end{array}$ & $\begin{array}{l}\mathrm{NC} \\
\text { group }\end{array}$ & Colostrum & $\begin{array}{l}\text { C } \\
\text { group }\end{array}$ & $\begin{array}{l}\mathrm{NC} \\
\text { group }\end{array}$ & Colostrum & $\begin{array}{l}\text { C } \\
\text { group }\end{array}$ & $\begin{array}{l}\mathrm{NC} \\
\text { group }\end{array}$ \\
\hline \multicolumn{11}{|l|}{$\begin{array}{l}\text { Colostrum proteins that were not observed in C } \\
\text { group plasma at } 14 \mathrm{~h} \text { after birth (colostrum pool) }\end{array}$} \\
\hline Alpha-lactalbumin & gi|125998 & 495 & ND & ND & 18 & ND & ND & 4 & ND & ND \\
\hline Alpha-S2-casein & gi|115658 & 2,636 & ND & ND & 111 & ND & ND & 12 & ND & ND \\
\hline Alpha-S1-casein precursor [Ovis aries] & gi| 57526469 & 5,240 & ND & ND & 194 & ND & ND & 13 & ND & ND \\
\hline Alpha-S2-casein [Ovis aries $]$ & gi 284025656 & 2,771 & ND & ND & 115 & ND & ND & 12 & ND & ND \\
\hline ATP synthase subunit $\alpha$ & F1MLB8 & 122 & ND & ND & 8 & ND & ND & 3 & ND & ND \\
\hline ATP synthase subunit $\beta$, mitochondrial & P00829 & 211 & ND & ND & 8 & ND & ND & 3 & ND & ND \\
\hline Beta-casein & gi $\mid 416752$ & 3,001 & ND & ND & 92 & ND & ND & 5 & ND & ND \\
\hline $\begin{array}{l}\text { Desmoplakin isoform i (Blast2Go, Similarity: } \\
96.35 \% \text { ) }\end{array}$ & E1BKT9 & 262 & ND & ND & 15 & ND & ND & 7 & ND & ND \\
\hline Elongation factor $1-\alpha$ & E1B9F6 & 270 & ND & ND & 12 & ND & ND & 3 & ND & ND \\
\hline Fatty acid-binding protein, heart & P10790 & 78 & ND & ND & 3 & ND & ND & 2 & ND & ND \\
\hline Ig mu chain - sheep & gi|478694 & 1,151 & ND & ND & 47 & ND & ND & 7 & ND & ND \\
\hline $\begin{array}{l}\text { Ig mu heavy chain } \mathrm{V} \text { region precursor - sheep } \\
\text { (fragment) }\end{array}$ & gi $\mid 1083106$ & 114 & ND & ND & 7 & ND & ND & 2 & ND & ND \\
\hline $\begin{array}{l}\text { Ig gamma } 2 \text { heavy chain constant } \\
\text { region [Capra hircus] }\end{array}$ & gi|147744654 & 1,089 & ND & ND & 48 & ND & ND & 3 & ND & ND \\
\hline $\begin{array}{l}\text { Ig lambda-2b light chain variable } \\
\text { region }[\text { Ovis aries] }\end{array}$ & gi $\mid 2746691$ & 74 & ND & ND & 5 & ND & ND & 2 & ND & ND \\
\hline $\begin{array}{l}\text { Junction plakoglobin (Blast2Go, Similarity: } \\
98.35 \% \text { ) }\end{array}$ & F1N3P9 & 92 & ND & ND & 4 & ND & ND & 3 & ND & ND \\
\hline Keratin, type I cytoskeletal 17 & A1L595 & 1,710 & ND & ND & 85 & ND & ND & 8 & ND & ND \\
\hline Keratin, type II cytoskeletal 75 & Q08D91 & 313 & ND & ND & 27 & ND & ND & 7 & ND & ND \\
\hline KRT5 protein & A5D7M6 & 1,519 & ND & ND & 72 & ND & ND & 20 & ND & ND \\
\hline $\begin{array}{l}\text { Milk fat globule EGF factor } 8 \text { protein, partial } \\
\text { [Ovis aries }]\end{array}$ & gi| 347803268 & 260 & ND & ND & 13 & ND & ND & 5 & ND & ND \\
\hline $\begin{array}{l}\text { Neutrophil gelatinase-associated lipocalin isoform } 2 \\
\text { (Blast2Go, Similarity: } 86.45 \% \text { ) }\end{array}$ & E1B6Z6 & 111 & ND & ND & 5 & ND & ND & 3 & ND & ND \\
\hline Nucleobindin-1 & Q0P569 & 221 & ND & ND & 8 & ND & ND & 5 & ND & ND \\
\hline Peroxiredoxin-1 & Q5E947 & 125 & ND & ND & 7 & ND & ND & 4 & ND & ND \\
\hline $\begin{array}{l}\text { Polymeric Ig receptor (Blast2Go, } \\
\text { Similarity: } 81.7 \% \text { ) }\end{array}$ & F1MR22 & 211 & ND & ND & 11 & ND & ND & 3 & ND & ND \\
\hline $\begin{array}{l}\text { Glycosylation-dependent cell } \\
\text { adhesion molecule } 1\end{array}$ & gi|22096365 & 97 & ND & ND & 8 & ND & ND & 4 & ND & ND \\
\hline $\begin{array}{l}\text { Secreted form Ig epsilon heavy chain } \\
\text { constant partial (Blast2Go, Similarity: } 74.3 \% \text { ) }\end{array}$ & G3N342 & 90 & ND & ND & 6 & ND & ND & 2 & ND & ND \\
\hline Type ii cytoskeletal 3 (Blast2Go, Similarity: $95.8 \%$ ) & G3MXL3 & 1,417 & ND & ND & 78 & ND & ND & 15 & ND & ND \\
\hline \multicolumn{11}{|c|}{$\begin{array}{l}\text { Proteins identified in DC group plasma at } 14 \mathrm{~h} \text { after } \\
\text { birth (NC group) }\end{array}$} \\
\hline Adiponectin & Q3Y5Z3 & ND & ND & 286 & ND & ND & 8 & ND & ND & 3 \\
\hline Alpha-2-antiplasmin & P28800 & ND & ND & 556 & ND & ND & 23 & ND & ND & 4 \\
\hline Antithrombin-III precursor [Ovis aries] & gi| 57164383 & ND & ND & 1,283 & ND & ND & 57 & ND & ND & 13 \\
\hline Apolipoprotein m (Blast2Go, Similarity: $93.7 \%$ ) & F1MYX2 & ND & ND & 100 & ND & ND & 6 & ND & ND & 3 \\
\hline Beta-2-glycoprotein 1 & P17690 & ND & ND & 539 & ND & ND & 18 & ND & ND & 5 \\
\hline $\begin{array}{l}\text { Bone marrow stromal cell antigen } 1 \text { (Blast2Go, } \\
\text { Similarity: } 86.65 \% \text { ) }\end{array}$ & F1MLP3 & ND & ND & 234 & ND & ND & 6 & ND & ND & 2 \\
\hline Carboxypeptidase $\mathrm{N}$ catalytic chain & Q2KJ83 & ND & ND & 138 & ND & ND & 6 & ND & ND & 3 \\
\hline $\begin{array}{l}\text { Chain D, Crystal Structure Determination Of Sheep } \\
\text { Methemoglobin At } 27 \text { Anostrom Resolution }\end{array}$ & gi||195927260 & ND & ND & 719 & ND & ND & 35 & ND & ND & 7 \\
\hline
\end{tabular}


Table 1 (Continued). Colostrum proteins identified in sheep colostrum and in lamb plasma from colostrum group (C group) and noncolostrum group (NC group)

\begin{tabular}{|c|c|c|c|c|c|c|c|c|c|c|}
\hline \multirow[b]{2}{*}{ Protein name } & \multirow[b]{2}{*}{$\begin{array}{l}\text { Accession } \\
\text { number }\end{array}$} & \multicolumn{3}{|c|}{ Mascot score } & \multicolumn{3}{|c|}{ Significant peptide matches ${ }^{1}$} & \multicolumn{3}{|c|}{ Unique peptide matches } \\
\hline & & Colostrum & $\begin{array}{l}\mathrm{C} \\
\text { group }\end{array}$ & $\begin{array}{l}\mathrm{NC} \\
\text { group }\end{array}$ & Colostrum & $\begin{array}{l}\mathrm{C} \\
\text { group }\end{array}$ & $\begin{array}{l}\mathrm{NC} \\
\text { group }\end{array}$ & Colostrum & $\begin{array}{l}\mathrm{C} \\
\text { group }\end{array}$ & $\underset{\text { group }}{\mathrm{NC}}$ \\
\hline $\begin{array}{l}\text { Coagulation factor a1 polypeptide (Blast2Go, } \\
\text { Similarity: } 94.3 \% \text { ) }\end{array}$ & F1MW44 & ND & ND & 134 & ND & ND & 6 & ND & ND & 2 \\
\hline Coagulation factor XIII, B polypeptide & Q2TBQ1 & ND & ND & 137 & ND & ND & 10 & ND & ND & 4 \\
\hline Complement C1s subcomponent & Q0VCX1 & ND & ND & 188 & ND & ND & 8 & ND & ND & 3 \\
\hline $\begin{array}{l}\text { Complement component 4a (Rodgers blood group) } \\
\text { (Blast2Go, Similarity: } 90.3 \% \text { ) }\end{array}$ & F1N2Q0 & ND & ND & 1,076 & ND & ND & 49 & ND & ND & 15 \\
\hline Complement factor B [Ovis aries] & gi|148645283 & ND & ND & 653 & ND & ND & 34 & ND & ND & 15 \\
\hline $\begin{array}{l}\text { Extracellular matrix protein } 1 \text { (Blast2Go, Similarity: } \\
81.65 \% \text { ) }\end{array}$ & F1MWT6 & ND & ND & 251 & ND & ND & 11 & ND & ND & 4 \\
\hline Fetuin-B & Q58D62 & ND & ND & 142 & ND & ND & 9 & ND & ND & 3 \\
\hline Fibulin 1 (Blast2Go, Similarity: 93.9\%) & F1MYN5 & ND & ND & 108 & ND & ND & 6 & ND & ND & 3 \\
\hline Haptoglobin & gi $\mid 226709030$ & ND & ND & 237 & ND & ND & 13 & ND & ND & 7 \\
\hline Haptoglobin [Rupicapra rupicapra] & gi| 307742657 & ND & ND & 351 & ND & ND & 15 & ND & ND & 8 \\
\hline Hemoglobin gamma & gi 229222 & ND & ND & 827 & ND & ND & 36 & ND & ND & 5 \\
\hline Histidine-rich glycoprotein & F1MKS5 & ND & ND & 218 & ND & ND & 12 & ND & ND & 3 \\
\hline Kininogen-1 & P01044 & ND & ND & 305 & ND & ND & 10 & ND & ND & 3 \\
\hline Leucine-rich $\alpha$-2-glycoprotein 1 & Q2KIF2 & ND & ND & 119 & ND & ND & 7 & ND & ND & 3 \\
\hline Lumican & Q05443 & ND & ND & 275 & ND & ND & 16 & ND & ND & 5 \\
\hline $\begin{array}{l}\text { Pigment epithelium-derived factor precursor } \\
\text { [Ovis aries] }\end{array}$ & gi $\mid 213021132$ & ND & ND & 699 & ND & ND & 27 & ND & ND & 10 \\
\hline Plasma serine protease inhibitor & Q9N2I2 & ND & ND & 80 & ND & ND & 6 & ND & ND & 3 \\
\hline Proteasome subunit $\beta$ type- 6 & Q3MHN0 & ND & ND & 69 & ND & ND & 3 & ND & ND & 2 \\
\hline Protein HP-20 homolog & Q2KIT0 & ND & ND & 133 & ND & ND & 5 & ND & ND & 3 \\
\hline Prothrombin precursor [Ovis aries] & gi 261244968 & ND & ND & 1,188 & ND & ND & 45 & ND & ND & 11 \\
\hline Angiotensinogen & gi|1703309 & ND & ND & 534 & ND & ND & 21 & ND & ND & 6 \\
\hline Carbonic anhydrase 2 & gi 118582300 & ND & ND & 285 & ND & ND & 13 & ND & ND & 4 \\
\hline Serpin A3-2 & A2I7M9 & ND & ND & 910 & ND & ND & 51 & ND & ND & 6 \\
\hline Serpin A3-5 & A2I7N1 & ND & ND & 1,222 & ND & ND & 84 & ND & ND & 6 \\
\hline SERPIND1 protein & A6QPP2 & ND & ND & 154 & ND & ND & 11 & ND & ND & 5 \\
\hline Serum albumin & P02769 & ND & ND & 15,860 & ND & ND & 479 & ND & ND & 22 \\
\hline Superoxide dismutase $[\mathrm{Cu}-\mathrm{Zn}]$ & A3KLR9 & ND & ND & 83 & ND & ND & 3 & ND & ND & 4 \\
\hline $\begin{array}{l}\text { Transferrin receptor protein } 1 \text { (Blast2Go, Similarity: } \\
87.9 \% \text { ) }\end{array}$ & E1BIG6 & ND & ND & 126 & ND & ND & 9 & ND & ND & 4 \\
\hline Transferrin receptor, partial [Ovis aries] & gi|369726201 & ND & ND & 110 & ND & ND & 6 & ND & ND & 2 \\
\hline
\end{tabular}

${ }^{1}$ Biological replicates from $\mathrm{C}$ group had a false discovery rate (FDR) $\leq 1.24$ and $\leq 2.20 \%$, respectively; biological replicates from NC group had an FDR $\leq 1.80 \%$ and $\leq 1.92 \%$, respectively; technical replicates from the pool of colostrum had an FDR $\leq 2.53 \%$ and $\leq 3.57 \%$, respectively.

${ }^{2}$ Nondetectable. 
be even more abundant in colostrum than in plasma. Colostrum clearly contributes to the health of the newborn, with several proteins that provide immunomodulatory effects, as reviewed by Bendixen et al. (2011). The iTRAQ labeling approach allowed analyses of the relative changes in immunomodulatory colostrum proteins as an effect of colostrum access in newborn lambs.

Colostrum Proteins Detected in C Group Plasma at 14 h After Birth. Immunoglobulins were mainly found to be absorbed and transferred to $\mathrm{C}$ group plasma after colostrum feeding. These findings are in agreement with Hurley and Theil (2011) and MorenoIndias et al. (2012), who reported immunoglobulins to be one of the most crucial proteins involved in PIT.

Colostrum Proteins Not Detected in C Group Plasma at 14 h After Birth. The subset of proteins that were identified in only colostrum (Table 1) and therefore apparently not absorbed from the colostrum includes proteins such as caseins and $\alpha$-lactalbumin. Colostrum is known to contain high amounts of immunoglobulins. In our studies, all immunoglobulin isoforms seemed to be efficiently absorbed to plasma, and indeed, these colostrum proteins dominated the plasma proteome of the colostrum-fed animals. However, additional highly abundant colostrum proteins, such as caseins and $\alpha$-lactalbumin, were not observed in lamb plasma. This indicates that their effect may be related to protective functions in the intestine of suckling animals. It has been noted that caseins act as bioactive peptide precursors with antimicrobial activity (Lahov and Regelson, 1996), suggesting that proteases can also play a role in the host defense. Furthermore, it has been recently shown that $\alpha$-lactalbumin plays a role as an immunomodulator in human and cow colostrum and milk (Montagne et al., 2000; Korhonen and Pihlanto, 2007; Marnila and Korhonen, 2011).

Indeed, a wide range of colostrum proteins was not detectable in plasma of colostrum animals. These included proteins such as neutrophil gelatinase-associated lipocalin isoform 2, peptidoglycan recognition protein 1, and junction plakoglobin, which all provide protection against bacterial infections. The first acts as an iron-trafficking protein (Yang et al., 2002), the second interferes with peptidoglycan biosynthesis (Liu et al., 2001; Lu et al., 2006), and junction plakiglobin, in conjunction with MUC-1, prevents pathogens from reaching the cell surface ( $\mathrm{Li}$ et al., 2003; Moncada et al., 2003). Moreover, proteins such as calcium binding protein, matrix gla protein, and nucleobindin-1, which take part in $\mathrm{Ca}^{2+}$ transport, or adipocyte fatty acidbinding protein, which participates in lipid transport, were observed in colostrum but not detectable in plasma after suckling. 
Proteins Detected in NC Group Plasma at 14 $h$ After Birth. Our findings clearly reflect how noncolostrum lambs showed a wide range of plasma proteins related to stress, inflammation, coagulation, catabolic metabolism, and cell destruction. The presence of proteins such as haptoglobin or different complement factors are indicative of stress in this group of lambs, probably related to colostrum deprivation, and therefore lack of energy intake. Thus, the presence of several proteins that take part during catabolic metabolism (adiponectin and plasma serine protease inhibitor, among others) were observed, together with proteins that are involved in the blood coagulation processes including coagulation factor a1 and XIII, $\alpha-2$ antiplasmin, kininogen-1, or serpin A3-2, A3-5, and D1. This observation may be related to the fact that the coagulation system appears to be activated and upregulated during periods of acute stress (Binev et al., 2006; Wirtz et al., 2008; Austin et al., 2012). Further studies are needed because the present data cannot confirm that the presence of these proteins in $\mathrm{NC}$ group is related to acute stress and not to the dilution factor that can follow colostrum intake in blood plasma.

\section{Protein Quantification Using an iTRAQ Approach}

In total, 148 proteins were observed and quantified from the shotgun proteome data. Of these, 31 proteins were normally distributed in at least 3 out of the 4 biological replicates in each of the 4 studied groups (C and $\mathrm{NC}$ groups at 2 and $14 \mathrm{~h}$ after birth, respectively). These were further analyzed for their relative abundance in plasma from both studied groups (C and $\mathrm{NC}$ groups) at 2 and $14 \mathrm{~h}$ after birth. Eight proteins were increased in the $\mathrm{C}$ group at $14 \mathrm{~h}$ after birth.

Table 2 shows significant $(P<0.05)$ protein ratio changes between $\mathrm{C}$ and $\mathrm{NC}$ groups during the experimental period. In reference to apolipoproteins, 3 different classes (apolipoprotein A-IV, B-100, and E) were found to be relatively increased in the $\mathrm{C}$ group at 14 $\mathrm{h}$ after birth due to colostrum feeding. These results are in agreement with those of Hernández-Castellano et al. (2014b), who observed that lambs fed with colostrum had a higher apolipoprotein A-IV concentration in blood than lambs not fed with colostrum during the first hours of life $(14 \mathrm{~h})$. The primary function of apolipoproteins in the efficacy of fat absorption by the intestine has been described in detail (Mahley and Rall, 2000; Kendrick et al., 2001; Stan et al., 2003; Simon et al., 2011). Fat absorption plays an essential role in newborn lambs, because colostrum is necessary not only for immune protection, but also as the only energy source at this early period after birth. Along with these findings, a relationship with the immune response has also been described. In particular, apolipoprotein B-100 and apolipoprotein-E have been demonstrated to be an innate barrier against infections (Maezawa et al., 2006; Peterson et al., 2008). Furthermore, it has been observed that apolipoprotein A-IV not only exhibits a protective effect against external agents (Vowinkel et al., 2004), but also serves to reduce gastric secretions (Okumura et al., 1994). This, in conjunction with the increase of trypsin inhibitor produced in the C group, promotes the absorption of proteins with their native structure.

Moreover, several acute-phase proteins, such as fibrinogen $\alpha$ chain, tetranectin, and ceruloplasmin, were also increased in plasma after colostrum feeding. The first of these proteins is the major precursor of blood clots (Tamzali et al., 2001) but also takes part in inflammation, stimulating the adhesion, migration, chemotaxis, and phagocytosis of monocytes and macrophages to the point of infection (Akassoglou and Strickland, 2002; Gånheim et al., 2003). Similarly, Hernández-Castellano et al. (2014b) observed an increase in fibrinogen $\mu$-chain concentration in blood plasma of lambs after colostrum intake, using a differential in-gel electrophoresis (DIGE) approach. Tetranectin is an active player in the activation of plasmin (Holtet et al., 1997), stimulating neutrophil migration to the infection (Renckens et al., 2006). Previously, ceruloplasmin has been described as a major copper and iron transporter, but this protein can also be involved in defense via its ferroxidase activity, which may drive iron homeostasis in a direction unfavorable to invasive organisms (Mazumder et al., 1997).

Table 2 shows that colostrum intake resulted in a relative increase of 8 plasma proteins in the $\mathrm{C}$ group. These proteins, observed using the iTRAQ LC-MS/ MS approach, were detected in both groups of animals (C and NC groups) as well as in the pool of sheep colostrum using SDS-PAGE LC-MS/MS. Because of the wide range of proteins present in colostrum and blood, no perfect proteomics approach exists that can provide a full characterization of these kind of samples; thus, the combination of different proteomic techniques is frequently suggested (Hernández-Castellano et al., 2014a). Results of this study using SDS-PAGE LCMS/MS in combination with an iTRAQ LC-MS/MS approach demonstrate that colostrum is essential not only for its immunoglobulin content, but also for the nonimmunoglobulin proteins that play a fundamental role in the activation and attraction of immune cells and low gastric secretion, among others. The information reported in this paper contributes comprehensive proteomics data, identifying proteins that may pass from the colostrum to the lamb's systemic circulation. Nevertheless, further studies for absolute quantitation 
using selected reaction monitoring will be necessary to understand the function of colostrum proteins and their relation to PIT. Additionally, this study provides a solid foundation for future studies that could identify important proteins to consider when developing an alternative colostrum source with putative implications in sheep production.

\section{CONCLUSIONS}

The results of this work described the presence of 70 proteins in the sheep colostrum proteome. Moreover, 8 proteins were increased in lamb blood plasma after colostrum intake. Understanding the uptake and effect of colostrum is important in reducing lamb mortality rates related to artificial rearing and, thus, in increasing the economic benefit of sheep farmers. Further proteomic studies will be necessary, particularly using the selected reaction monitoring approach, to increase the general knowledge about the role of colostrum in the PIT.

\section{ACKNOWLEDGMENTS}

L. E. Hernández-Castellano acknowledges financial support from the Formación del Profesorado Universitario (FPU) program (Ministry of Education, Madrid, Spain). A. M. Almeida acknowledges the support from SFRH/BPD/90916/2012 from Fundação para a Ciência e Tecnologia (Lisbon, Portugal). All authors are members of the international consortium COST action FA1002: Farm Animals Proteomics (www.costfaproteomics.org) funded by the European Science Foundation (Brussels, Belgium) to whom the network support is acknowledged, as well as Short Term Scientific Mission reference COST-STSM-FA1002-10773 that made this work and collaboration possible. The authors thank David Eckersall (University of Glasgow, UK) and Samantha Wall (University of Bern, Switzerland) for critically reviewing this manuscript.

\section{REFERENCES}

Akassoglou, K., and S. Strickland. 2002. Nervous system pathology: The fibrin perspective. Biol. Chem. 383:37-45.

Albera, E., and M. Kankofer. 2009. Antioxidants in colostrum and milk of sows and cows. Reprod. Domest. Anim. 44:606-611.

Argüello, A., N. Castro, J. Capote, J. W. Tyler, and N. M. Holloway. 2004a. Effect of colostrum administration practices on serum IgG in goat kids. Livest. Prod. Sci. 90:235-239.

Argüello, A., N. Castro, M. J. Zamorano, A. Castroalonso, and J. Capote. 2004b. Passive transfer of immunity in kid goats fed refrigerated and frozen goat colostrum and commercial sheep colostrum. Small Rumin. Res. 54:237-241.

Austin, A. W., P. H. Wirtz, S. M. Patterson, M. Stutz, and R. von Kanel. 2012. Stress-induced alterations in coagulation: Assessment of a new hemoconcentration correction technique. Psychosom. Med. 74:288-295.
Bendixen, E., M. Danielsen, K. Hollung, E. Gianazza, and I. Miller. 2011. Farm animal proteomics-A review. J. Proteomics 74:282 293.

Binev, R., P. Slavova, and S. Laleva. 2006. Effects of fasting on blood cells from lambs of various breeds. Trakia J. Sci. 4:37-43.

Boersema, P. J., T. T. Aye, T. A. van Veen, A. J. Heck, and S. Mohammed. 2008. Triplex protein quantification based on stable isotope labeling by peptide dimethylation applied to cell and tissue lysates. Proteomics 8:4624-4632.

Bradford, M. M. 1976. A rapid and sensitive method for the quantitation of microgram quantities of protein utilizing the principle of protein-dye binding. Anal. Biochem. 72:248-254.

Bury, A. F. 1981. Analysis of protein and peptide mixtures: Evaluation of three sodium dodecyl sulphate-polyacrylamide gel electrophoresis buffer systems. J. Chromatogr. A 213:491-500.

Castro, N., J. Capote, S. Alvarez, and A. Arguello. 2005. Effects of lyophilized colostrum and different colostrum feeding regimens on passive transfer of immunoglobulin $\mathrm{G}$ in Majorera goat kids. J. Dairy Sci. 88:3650-3654.

Castro, N., J. Capote, R. M. Bruckmaier, and A. Arguello. 2011. Management effects on colostrogenesis in small ruminants: A review. J. Appl. Anim. Res. 39:85-93.

Castro-Alonso, A., N. Castro, J. Capote, A. Morales-DelaNuez, I. Moreno-Indias, D. Sanchez-Macias, P. Herraez, and A. Argüello. 2008. Short communication: Apoptosis regulates passive immune transfer in newborn kids. J. Dairy Sci. 91:2086-2088.

Constant, S. B., M. M. LeBlanc, E. F. Klapstein, D. E. Beebe, H. M. Leneau, and C. J. Nunier. 1994. Serum immunoglobulin G concentration in goat kids fed colostrum or a colostrum substitute. J. Am. Vet. Med. Assoc. 205:1759-1762

Danielsen, M., L. J. Pedersen, and E. Bendixen. 2011. An in vivo characterization of colostrum protein uptake in porcine gut during early lactation. J. Proteomics 74:101-109.

Dupont, D., B. Remond, and J. C. Collin. 1998. ELISA determination of plasmin and plasminogen in milk of individual cows managed without the dry period. Milchwissenschaft 53:66-69.

Dyrlund, T. F., E. T. Poulsen, C. Scavenius, K. W. Sanggaard, and J. J. Enghild. 2012. MS Data Miner: A web-based software tool to analyze, compare, and share mass spectrometry protein identifications. Proteomics 12:2792-2796.

Faulkner, S., G. Elia, M. P. Mullen, P. O'Boyle, M. J. Dunn, and D. Morris. 2012. A comparison of the bovine uterine and plasma proteome using iTRAQ proteomics. Proteomics 12:2014-2023.

Gabriël, S., P. Geldhof, I. K. Phiri, P. Cornillie, B. M. Goddeeris, and J. Vercruysse. 2005. Placental transfer of immunoglobulins in cattle infected with Schistosoma mattheei. Vet. Immunol. Immunopathol. 104:265-272.

Gånheim, C., C. Hulten, U. Carlsson, H. Kindahl, R. Niskanen, and K. P. Waller. 2003. The acute phase response in calves experimentally infected with bovine viral diarrhoea virus and/or Mannheimia haemolytica. J. Vet. Med. B Infect. Dis. Vet. Public Health 50:183-190.

Gannon, J., and K. Ohlendieck. 2012. Subproteomic analysis of basic proteins in aged skeletal muscle following offgel pre-fractionation. Mol. Med. Rep. 5:993-1000.

Guilloteau, P., T. Corring, P. Garnot, P. Martin, R. Toullec, and G. Durand. 1983. Effects of age and weaning on enzyme-activities of abomasum and pancreas of the lamb. J. Dairy Sci. 66:2373-2385.

Hernández-Castellano, L. E., A. M. Almeida, N. Castro, and A. Argüello. 2014a. The colostrum proteome, ruminant nutrition and immunity: A review. Curr. Protein Pept. Sci. 15:64-74.

Hernández-Castellano, L. E., A. M. Almeida, A. Ventosa, A. Coelho, N. Castro, and A. Argüello. 2014b. The effect of colostrum intake on blood plasma proteome profile in newborn lambs: Low abundance proteins. BMC Vet. Res. 10:85.

Hernández-Castellano, L. E., A. Morales-delaNuez, D. Sánchez-Macías, I. Moreno-Indias, A. Torres, J. Capote, A. Argüello, and N. Castro. 2015. The effect of colostrum source (goat vs. sheep) and timing of the first colostrum feeding ( $2 \mathrm{~h}$ vs. $14 \mathrm{~h}$ after birth) on body weight and immune status of artificial rearing newborn lambs. J. Dairy Sci. 97:204-210. http://dx.doi.org/10.3168/jds.2014-8350. 
Higaki, S., M. Nagano, S. Katagiri, and Y. Takahashi. 2013. Effects of parity and litter size on the energy contents and immunoglobulin G concentrations of Awassi ewe colostrum. Turk. J. Vet. Anim. Sci. 37:109-112.

Holtet, T. L., J. H. Graversen, I. Clemmensen, H. C. Thogersen, and M. Etzerodt. 1997. Tetranectin, a trimeric plasminogen-binding C-type lectin. Protein Sci. 6:1511-1515.

Honkanen-Buzalski, T., and M. Sandholm. 1981. Trypsin-inhibitors in mastitic milk and colostrum - Correlation between trypsin-inhibitor capacity, bovine serum albumin and somatic cell contents. J. Dairy Res. 48:213-223.

Hortin, G. L., and D. Sviridov. 2010. The dynamic range problem in the analysis of the plasma proteome. J. Proteomics 73:629-636.

Hurley, W. L., and P. K. Theil. 2011. Perspectives on immunoglobulins in colostrum and milk. Nutrients 3:442-474.

Johnson, J. L., S. M. Godden, T. Molitor, T. Ames, and D. Hagman. 2007. Effects of feeding heat-treated colostrum on passive transfer of immune and nutritional parameters in neonatal dairy calves. J. Dairy Sci. 90:5189-5198.

Kendrick, J. S., L. Chan, and J. A. Higgins. 2001. Superior role of apolipoprotein B48 over apolipoprotein B100 in chylomicron assembly and fat absorption: an investigation of apobec-1 knock-out and wild-type mice. Biochem. J. 356:821-827.

Klobasa, F., E. Werhahn, and J. E. Butler. 1987. Composition of sow milk during lactation. J. Anim. Sci. 64:1458-1466.

Korhonen, H., and A. Pihlanto. 2007. Technological options for the production of health-promoting proteins and peptides derived from milk and colostrum. Curr. Pharm. Des. 13:829-843.

Lahov, E., and W. Regelson. 1996. Antibacterial and immunostimulating casein-derived substances from milk: Casecidin, isracidin peptides. Food Chem. Toxicol. 34:131-145.

Le, A., L. D. Barton, J. T. Sanders, and Q. Zhang. 2011. Exploration of bovine milk proteome in colostral and mature whey using an ion-exchange approach. J. Proteome Res. 10:692-704.

Leitner, G., O. Krifucks, S. Jacoby, Y. Lavi, and N. Silanikove. 2008. Concentrations of ganglioside type M1 and immunoglobulin G in colostrum are inversely related to bacterial infection at early lactation in cows. J. Dairy Sci. 91:3337-3342.

Lérias, J. R., L. E. Hernández-Castellano, A. Suárez-Trujillo, N. Castro, A. Pourlis, and A. M. Almeida. 2014. The mammary gland in small ruminants: Major morphological and functional events underlying milk production-A review. J. Dairy Res. 81:304-318. http://dx.doi.org/10.1017/S0022029914000235.

Li, Y., W. H. Yu, J. Ren, W. Chen, L. Huang, S. Kharbanda, M. Loda, and D. Kufe. 2003. Heregulin targets gamma-catenin to the nucleolus by a mechanism dependent on the DF3/MUC1 oncoprotein. Mol. Cancer Res. 1:765-775.

Liu, C., Z. Xu, D. Gupta, and R. Dziarski. 2001. Peptidoglycan recognition proteins: a novel family of four human innate immunity pattern recognition molecules. J. Biol. Chem. 276:34686-34694.

Lu, X., M. Wang, J. Qi, H. Wang, X. Li, D. Gupta, and R. Dziarski. 2006. Peptidoglycan recognition proteins are a new class of human bactericidal proteins. J. Biol. Chem. 281:5895-5907.

Maezawa, I., N. Maeda, T. J. Montine, and K. S. Montine. 2006. Apolipoprotein E-specific innate immune response in astrocytes from targeted replacement mice. J. Neuroinflamm. 3:10.

Mahley, R. W., and S. C. Rall. 2000. Apolipoprotein E: Far more than a lipid transport protein. Annu. Rev. Genomics Hum. Genet. $1: 507-537$.

Marnila, P., and H. Korhonen. 2011. Milk | Colostrum. Pages 591-597 in Encyclopedia of Dairy Sciences. 2nd ed. J. W. Fuquay, ed. Academic Press, San Diego, CA.

Mazumder, B., C. K. Mukhopadhyay, A. Prok, M. K. Cathcart, and P. L. Fox. 1997. Induction of ceruloplasmin synthesis by IFN-gamma in human monocytic cells. J. Immunol. 159:1938-1944.

McDonald, T. L., M. A. Larson, D. R. Mack, and A. Weber. 2001. Elevated extrahepatic expression and secretion of mammary-associated serum amyloid A 3 (M-SAA3) into colostrum. Vet. Immunol. Immunopathol. 83:203-211.

Millioni, R., S. Tolin, L. Puricelli, S. Sbrignadello, G. P. Fadini, P. Tessari, and G. Arrigoni. 2011. High abundance proteins depletion vs low abundance proteins enrichment: Comparison of methods to reduce the plasma proteome complexity. PLoS ONE 6:e19603.

Moncada, D. M., S. J. Kammanadiminti, and K. Chadee. 2003. Mucin and Toll-like receptors in host defense against intestinal parasites. Trends Parasitol. 19:305-311.

Montagne, P. M., M. L. Cuillière, C. M. Molé, M. C. Béné, and G. C. Faure. 2000. Dynamics of the main immunologically and nutritionally available proteins of human milk during lactation. J. Food Compos. Anal. 13:127-137.

Moore, M., J. W. Tyler, M. Chigerwe, M. E. Dawes, and J. R. Middleton. 2005. Effect of delayed colostrum collection on colostral IgG concentration in dairy cows. J. Am. Vet. Med. Assoc. 226:13751377.

Moreno-Indias, I., D. Sanchez-Macias, N. Castro, A. Morales-delaNuez, L. E. Hernandez-Castellano, J. Capote, and A. Arguello. 2012. Chemical composition and immune status of dairy goat colostrum fractions during the first $10 \mathrm{~h}$ after partum. Small Rumin. Res. 103:220-224.

Moretti, D. B., L. Kindlein, P. Pauletti, and R. Machado-Neto. 2010a. IgG absorption by Santa Ines lambs fed Holstein bovine colostrum or Santa Ines ovine colostrum. Animal 4:933-937.

Moretti, D. B., P. Pauletti, L. Kindlein, and R. Machado-Neto. 2010b. Enteric cell proliferation in newborn lambs fed bovine and ovine colostrum. Livest. Sci. 127:262-266.

Nissen, A., E. Bendixen, K. L. Ingvartsen, and C. M. Rontved. 2012. In-depth analysis of low abundant proteins in bovine colostrum using different fractionation techniques. Proteomics 12:2866-2878.

Okumura, T., K. Fukagawa, P. Tso, I. L. Taylor, and T. N. Pappas. 1994. Intracisternal injection of apolipoprotein A-IV inhibits gastric secretion in pylorus-ligated conscious rats. Gastroenterology 107:1861-1864.

Ontsouka, C. E., R. M. Bruckmaier, and J. W. Blum. 2003. Fractionized milk composition during removal of colostrum and mature milk. J. Dairy Sci. 86:2005-2011.

Oviedo-Boyso, J., J. J. Valdez-Alarcon, M. Cajero-Juarez, A. OchoaZarzosa, J. E. Lopez-Meza, A. Bravo-Patino, and V. M. Baizabal-Aguirre. 2007. Innate immune response of bovine mammary gland to pathogenic bacteria responsible for mastitis. J. Infect. 54:399-409.

Perkins, D. N., D. J. C. Pappin, D. M. Creasy, and J. S. Cottrell. 1999. Probability-based protein identification by searching sequence databases using mass spectrometry data. Electrophoresis 20:3551-3567.

Petersen, L. J., M. A. Sorensen, M. C. Codrea, H. D. Zacho, and E. Bendixen. 2013. Large pore dermal microdialysis and liquid chromatography-tandem mass spectroscopy shotgun proteomic analysis: A feasibility study. Skin Res. Technol. 19:424-431.

Peterson, M. M., J. L. Mack, P. R. Hall, A. A. Alsup, S. M. Alexander, E. K. Sully, Y. S. Sawires, A. L. Cheung, M. Otto, and H. D. Gresham. 2008. Apolipoprotein B is an innate barrier against invasive Staphylococcus aureus infection. Cell Host Microbe 4:555-566.

Picotti, P., B. Bodenmiller, L. N. Mueller, B. Domon, and R. Aebersold. 2009. Full dynamic range proteome analysis of $S$. cerevisiae by targeted proteomics. Cell 138:795-806.

Quigley, J. D. 3rd, A. F. Carson, and J. Polo. 2002. Immunoglobulin derived from bovine plasma as a replacement for colostrum in newborn lambs. Vet. Ther. 3:262-269.

Rainard, P., and C. Riollet. 2006. Innate immunity of the bovine mammary gland. Vet. Res. 37:369-400.

Ramos, J. J., A. Loste, L. M. Ferrer, A. Fernandez, N. Castro, A. Ortin, M. T. Verde, A. Arguello, and L. Figueras. 2010. Effect of addition of soybean trypsin inhibitor to colostrum on immunological status in goat kids. J. Anim. Physiol. Anim. Nutr. (Berl.) 94:93-98.

Reinhardt, T. A., and J. D. Lippolis. 2008. Developmental changes in the milk fat globule membrane proteome during the transition from colostrum to milk. J. Dairy Sci. 91:2307-2318.

Renckens, R., J. J. T. H. Roelofs, S. Florquin, and T. van der Poll 2006. Urokinase-type plasminogen activator receptor plays a role in neutrophil migration during lipopolysaccharide-induced perito- 
neal inflammation but not during Escherichia coli-induced peritonitis. J. Infect. Dis. 193:522-530.

Rodinova, H., V. Kroupova, J. Travnicek, M. Stankova, and L. Pisek. 2008. Dynamics of $\operatorname{IgG}$ in the blood serum of sheep with different selenium intake. Vet. Med. (Czech.) 53:260-265.

Rodríguez, C., N. Castro, J. Capote, A. Morales-delaNuez, I. MorenoIndias, D. Sanchez-Macias, and A. Arguello. 2009. Effect of colostrum immunoglobulin concentration on immunity in Majorera goat kids. J. Dairy Sci. 92:1696-1701.

Simon, T., V. R. Cook, A. Rao, and R. B. Weinberg. 2011. Impact of murine intestinal apolipoprotein A-IV expression on regional lipid absorption, gene expression, and growth. J. Lipid Res. 52:19841994.

Smith, G. W., and D. M. Foster. 2007. Short communication: Absorption of protein and immunoglobulin $\mathrm{G}$ in calves fed a colostrum replacer. J. Dairy Sci. 90:2905-2908.

Soares, R., C. Franco, E. Pires, M. Ventosa, R. Palhinhas, K. Koci, A. Martinho de Almeida, and A. Varela Coelho. 2012. Mass spectrometry and animal science: protein identification strategies and particularities of farm animal species. J. Proteomics 75:4190-4206.

Stan, S., E. Delvin, M. Lambert, E. Seidman, and E. Levy. 2003. Apo A-IV: An update on regulation and physiologic functions. Biochim. Biophys. Acta 1631:177-187.
Stelwagen, K., E. Carpenter, B. Haigh, A. Hodgkinson, and T. T. Wheeler. 2009. Immune components of bovine colostrum and milk. J. Anim. Sci. 87(Suppl.):3-9.

Tamzali, Y., J. F. Guelfi, and J. P. Braun. 2001. Plasma fibrinogen measurement in the horse: Comparison of Millar's technique with a chronometric technique and the QBC-Vet Autoreader. Res. Vet. Sci. 71:213-217.

Vowinkel, T., M. Mori, C. F. Krieglstein, J. Russell, F. Saijo, S. Bharwani, R. H. Turnage, W. S. Davidson, P. Tso, D. N. Granger, and T. J. Kalogeris. 2004. Apolipoprotein A-IV inhibits experimental colitis. J. Clin. Invest. 114:260-269.

Wirtz, P. H., L. S. Redwine, C. Baertschi, M. Spillmann, U. Ehlert, and R. von Kanel. 2008. Coagulation activity before and after acute psychosocial stress increases with age. Psychosom. Med. 70:476-481.

Yamada, M., K. Murakami, J. C. Wallingford, and Y. Yuki. 2002. Identification of low-abundance proteins of bovine colostral and mature milk using two-dimensional electrophoresis followed by microsequencing and mass spectrometry. Electrophoresis 23:1153-1160.

Yang, J., D. Goetz, J. Y. Li, W. Wang, K. Mori, D. Setlik, T. Du, H. Erdjument-Bromage, P. Tempst, R. Strong, and J. Barasch. 2002. An iron delivery pathway mediated by a lipocalin. Mol. Cell 10:1045-1056 